\title{
Nucleolar organizer region banding in crossbred and non-descript pigs of India
}

\author{
V. Harshini, K. Sakunthala Devi, B. Punya Kumari and J. Suresh
}

Department of Animal Genetics and Breeding, Sri Venkateswara Veterinary University, Tirupati, Andhra Pradesh, India. Corresponding author: V. Harshini, e-mail: kashuvemula15@gmail.com

Co-authors: KSD: kopparthi.s@gmail.com, BPK: punya67@yahoo.co.in, JS: jeepalyamsuresh@yahoo.co.in Received: 15-06-2018, Accepted: 16-08-2018, Published online: 01-10-2018

doi: 10.14202/vetworld.2018.1371-1375 How to cite this article: Harshini V, Devi KS, Kumari BP, Suresh J (2018) Nucleolar organizer region banding in crossbred and non-descript pigs of India, Veterinary World, 11(10): 1371-1375.

\begin{abstract}
Aim: The objective of this experiment was to study the nucleolar organizer region (NOR)-banding pattern in Large White Yorkshire (LWY) crossbred and non-descript pigs and finding differences in the number of NORs between animals and between genetic groups.
\end{abstract}

Materials and Methods: The experiment was carried out on 15 females, and 15 males of LWY crossbred and non-descript pigs to study NOR-banding pattern by employing ammoniacal silver staining technique.

Results: A total of 63 and 65 number of good metaphases were prepared in LWY crossbred, and non-descript pigs and a total of 168 and 143 number of NORs were detected on the $8^{\text {th }}$ and $10^{\text {th }}$ chromosomes in both genetic groups, respectively. The mean number of NORs per metaphase was 2.67 and 2.20 in LWY crossbred and non-descript pigs, respectively. LWY crossbred pig had high mean number of silver-stained NORs (Ag-NORs) per metaphase compared to non-descript pig. In general, it was observed that the highest frequency of metaphases (\%) examined had two number of NORs, while the lowest frequency (\%) had four number of NORs. The number of NORs observed per metaphase on secondary constrictions of the $8^{\text {th }}$ and $10^{\text {th }}$ chromosome pair in both genetic groups ranged from 2 to 4 . The Chi-square test of significance revealed that the observed frequencies do not differ significantly from the expected frequencies.

Conclusion: The results confirmed differences across breeds in occurrence and number of NORs on chromosomes in pigs. The mean numbers of NORs present per metaphase vary between the animals indicating the existence of polymorphism for the number of NORs. A higher number of Ag-NORs were observed on chromosome pair 10 in both the genetic groups. It was concluded that NORs were more morphologically distinct and greater on chromosome pair 10 than on pair 8, which suggests a dominant role of chromosome 10 in the global production of ribosomal RNA.

Keywords: silver-stained nucleolar organizer regions, large white Yorkshire crossbred pig, non-descript pig, silver staining.

\section{Introduction}

The nucleolar organizer regions (NORs) identified as secondary constrictions in mitotic chromosomes referred as NORs are responsible for the structure, organization, and formation of nucleoli in the process of cell protein synthesis [1], which are then a base for the establishment of ribosomal subunits, which facilitate the synthesis of proteins [2]. NOR bands constitute structural non-histone proteins that are specifically associated with NOR and bind to ammoniacal silver nitrate [3]. For Sus domestica, the NORs occur in the $8^{\text {th }}$ and $10^{\text {th }}$ pair of chromosomes on short arms close to the centromere $[4,5]$. Structure, number, and morphology of NOR may be specific to populations, species, and subspecies.

Changes in chromosome structure and number can alter the number and structure of NOR.

Copyright: Harshini, et al. Open Access. This article is distributed under the terms of the Creative Commons Attribution 4.0 International License (http://creativecommons.org/licenses/ by/4.0/), which permits unrestricted use, distribution, and reproduction in any medium, provided you give appropriate credit to the original author(s) and the source, provide a link to the Creative Commons license, and indicate if changes were made. The Creative Commons Public Domain Dedication waiver (http:// creativecommons.org/publicdomain/zero/1.0/) applies to the data made available in this article, unless otherwise stated.
Robertsonian translocations may cause losses of NOR. Species which have limited gene exchange due to geographical isolation, have elevated karyotype and NOR variety [6]. NOR banding can be practiced for chromosomal study with double satellites, chromosome polymorphisms and structural abnormalities involving satellite regions $[7,8]$. NORs size variants can be applied for studies on differentiation of pig breeds as well as estimation of genetic distance (or) evolutionary relationships in domestic pig (or) between domestic and wild pig [9]. NORs can play a role as candidate markers of parental species [10], chromosome markers in fish cytotaxonomy $[11,12]$.

The objective of this experiment was to study the NOR-banding pattern in Large White Yorkshire (LWY) crossbred and non-descript pigs and finding differences in the number of NORs between animals and between genetic groups.

\section{Materials and Methods}

\section{Ethical approval}

During collection of blood samples from pigs, attention had been paid to minimize pain to the animal and the Institutional Animal Ethics Committee clearance is not required since it involves the only collection of blood samples from experimental animals. 


\section{Experimental animals}

The present cytogenetic study was carried out on 15 males and 15 females of LWY crossbred pigs maintained at all India coordinated research project on pig, College of Veterinary Science, Tirupati, Chittoor district of Andhra Pradesh, and on non-descript pigs maintained by the farmers in and around Tirupati.

\section{Technique}

The photographs of crossbred and non-descript pig included in the present study are shown in Figures-1 and 2. Short-term lymphocyte culture technique, as described by Moorehead et al. [13] with slight modifications, was followed for karyotyping and the ammoniacal silver staining procedure as described by Howell and Black [14] was followed with minor modifications for NOR-banding technique. The unstained slides were heated on warmed up to $70^{\circ} \mathrm{C}$. About four drops of colloidal developer and eight drops of silver nitrate $(50 \%)$ were placed on coverslip and slides were kept on the coverslip to enable the chromosomes to take stain for $2 \mathrm{~min}$ (or) till the silver stain changed

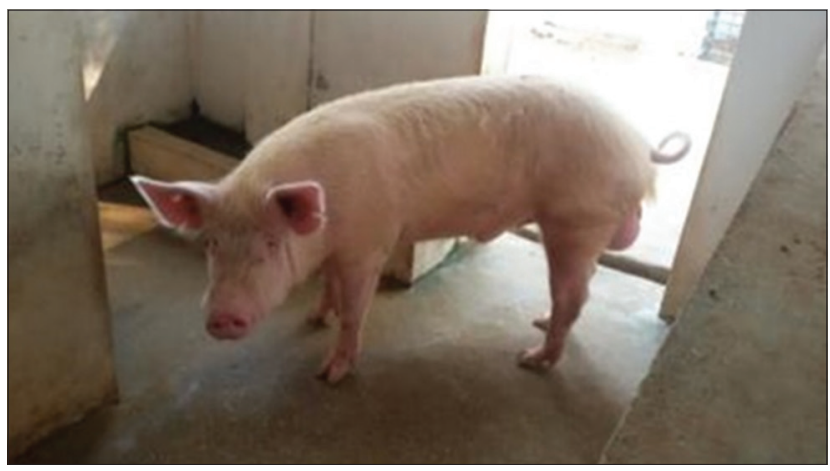

Figure-1: Large white Yorkshire crossbred male maintained in farm conditions (at all India Coordinated Research Project on pig, Tirupati).

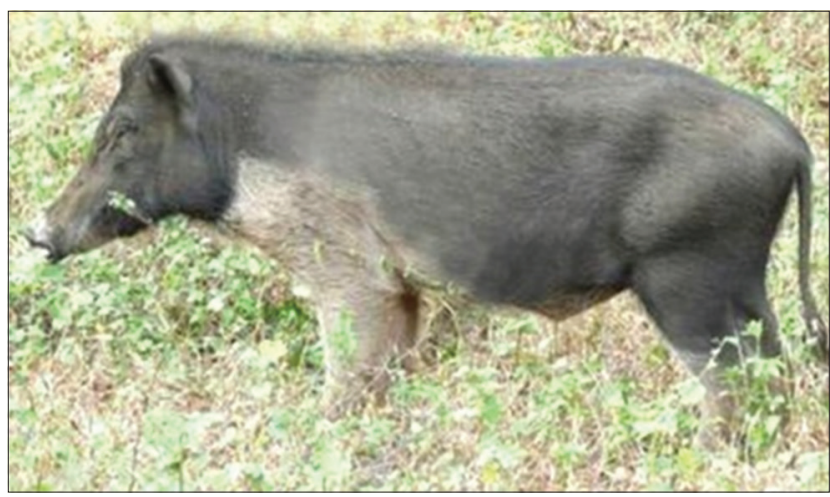

Figure-2: Non-descript male pig in a farmers herd at field conditions. to golden yellow color. The coverslip was removed, and excess stain was washed with deionized water and counterstained with $2 \%$ Giemsa for $20 \mathrm{~s}$. The air-dried slides were observed under a bright field microscope.

The silver-stained NORs (Ag-NORs) were visualized as black spherical bodies on yellow-brown chromosome arms. The good metaphases showing the NORs clearly were photographed and shown in Figures- 3 and 4 . The number of NORs per metaphase was counted and subjected to the analysis.

\section{Statistical analysis}

The frequency distribution of number of metaphases containing the Ag-NOR bands was tested for significance by Chi-square test [15].

\section{Results and Discussion}

In the present study, a total of 63 and 65 number of good metaphases were examined in LWY crossbred, and non-descript pig and a total of 168 and 143 NORs

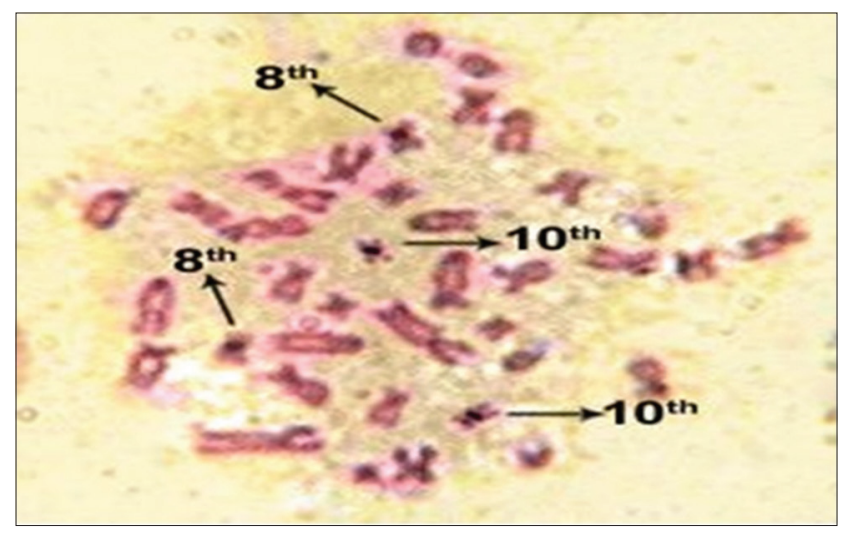

Figure-3: Nucleolar organizer region banding of large white Yorkshire crossbred male pigs.

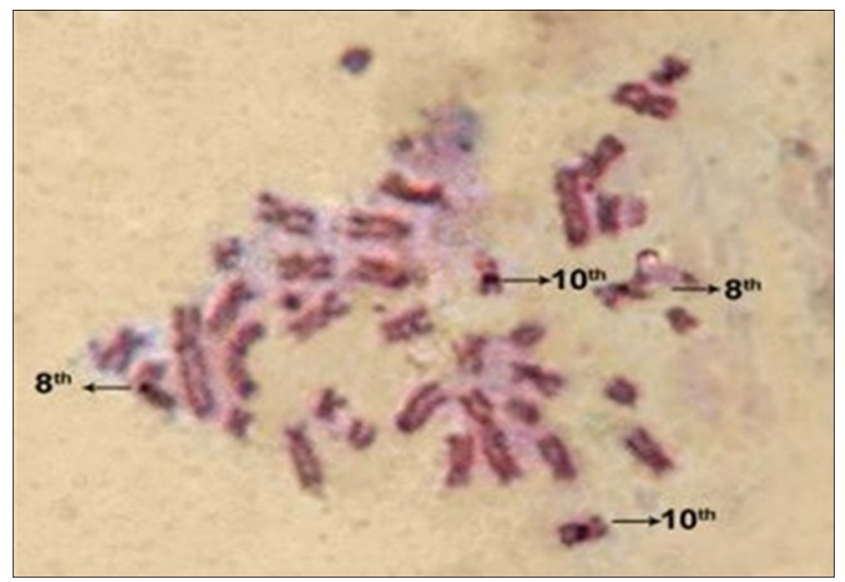

Figure-4: Nucleolar organizer region banding of nondescript male pigs.

Table-1: Number of metaphases examined, number of NORs detected and mean number of NORs per metaphase.

\begin{tabular}{lccc}
\hline Breed & $\begin{array}{c}\text { Number of metaphases } \\
\text { examined }\end{array}$ & $\begin{array}{c}\text { Number of NORs } \\
\text { detected }\end{array}$ & $\begin{array}{c}\text { Mean number of NORs per } \\
\text { metaphase }\end{array}$ \\
\hline LWY crossbred pigs & 63 & 168 & 2.67 \\
Non-descript pigs & 65 & 143 & 2.20 \\
\hline
\end{tabular}

NORs=Nucleolar organizer region, LWY=Large white Yorkshire 
were detected in both genetic groups, respectively (Table-1). The overall mean number of NORs observed per metaphase was 2.67 and 2.20 in LWY crossbred and non-descript pigs, while [16-18] reported similar values in Dutch Landrace, Yorkshire, Norwegian Landrace, Finish Landrace, Korean native, Xiang, and Min breed of pig. It was observed that LWY crossbred pig had high mean number of Ag-NORs per metaphase (2.67) compared to non-descript pig (2.20) (Table-1). The mean number of NORs present per metaphase in this study varies between the animals indicating the existence of polymorphism for the number of NORs. The highest frequency of metaphases (47.61\% in LWY crossbred and $81.54 \%$ in non-descript pigs) had two number of NORs, whereas the lowest frequency of metaphases $(7.94 \%$ in LWY crossbred and $3.07 \%$ in non-descript pigs) had four number of NORs (Table2 ). It was observed that the frequency of the metaphases reduced as the number of NORs per metaphase increased which was in accordance with the reports of Devi et al. [19]. The Chi-square test of significance

Table-2: Frequency distribution of NORs per metaphase in LWY and non-descript pigs.

\begin{tabular}{|c|c|c|c|c|c|}
\hline \multicolumn{2}{|c|}{$\begin{array}{l}\text { Number of } \\
\text { NORs per } \\
\text { metaphase }\end{array}$} & \multicolumn{2}{|c|}{$\begin{array}{c}\text { Frequency (number } \\
\text { of metaphases) }\end{array}$} & \multicolumn{2}{|c|}{ Percentage } \\
\hline LWY & ND & LWY & ND & LWY & ND \\
\hline 2 & 2 & 30 & 53 & 47.61 & 81.54 \\
\hline 3 & 3 & 28 & 10 & 44.44 & 15.39 \\
\hline 4 & 4 & 5 & 2 & 7.94 & 3.07 \\
\hline Total & & 63 & 65 & 100.00 & 100.00 \\
\hline
\end{tabular}

LWY=Large white Yorkshire, NORs=Nucleolar organizer regions

Table-3: Number of metaphases demonstrating the presence of Ag-NORs on chromosomes of LWY crossbred and non-descript pigs.

\begin{tabular}{|c|c|c|c|c|c|c|}
\hline \multirow[t]{2}{*}{ Breed } & \multicolumn{3}{|c|}{$\begin{array}{l}\text { Chromosome } \\
\text { pair } 8 \text { variant }\end{array}$} & \multicolumn{3}{|c|}{$\begin{array}{c}\text { Chromosome pair } \\
10 \text { variant }\end{array}$} \\
\hline & $+/+$ & $+/-$ & $-1-$ & $+/+$ & $+/-$ & $-1-$ \\
\hline $\begin{array}{l}\text { LWY crossbred } \\
\text { pigs }\end{array}$ & 09 & 34 & 20 & 53 & 10 & - \\
\hline $\begin{array}{l}\text { Non-descript } \\
\text { pigs }\end{array}$ & 05 & 51 & 09 & 17 & 48 & - \\
\hline Total & 14 & 86 & 27 & 49 & 79 & - \\
\hline
\end{tabular}

LWY=Large white Yorkshire, Ag-NORs=Silver-stained nucleolar organizer region as revealed that the observed frequencies do not differ significantly from the expected frequencies.

Prominent NORs were observed on chromosome number 10, suggesting a dominant role of the $10^{\text {th }}$ chromosome in the production of ribosomal RNA, while the NORs of chromosome $8^{\text {th }}$ were varied in staining and showed lesser Ag-NORs. Słota [5] and Mellink et al. [20] indicated that the silver deposits on pig chromosomes of pair 10 were greater than those of pair 8 in the individuals analyzed.

In LWY crossbred pig, single silver deposit [21] was observed most frequently on the $8^{\text {th }}$ chromosome pair, whereas only in nine cases two silver deposits occurred on both homologous chromosome pairs. Of total 63 metaphases, 20 number of metaphases had no Ag-NORs on chromosome number 8. On chromosome pair 10, it was observed that two silver deposits were most frequent [22] and 10 metaphases were found with single silver deposits (Table-3).

In non-descript pigs, 51 single silver deposits were observed on one homologous pair of chromosome pair $8^{\text {th }}$ and only five cases were shown with two silver deposits on both homologous chromosome and nine number of cases had no silver deposits. On chromosome pair 10, the majority of metaphases showed single silver [23] deposits on one homologous pair, whereas 17 number of cases recorded with single silver deposits on both homologous pairs (Table-3).

The frequency of occurrence of Ag-NORs in both the breeds and the presence $(+)$ or absence $(-)$ of silver deposits on the chromosome pair 8 and 10 is given in Table-4. On the $8^{\text {th }}$ chromosome pair, a total of 52 and 61 number of NORs were observed with mean number of 1.76 and 2.16 regions per animal in LWY crossbred and non-descript pigs. The percentage share of deposits on the $8^{\text {th }}$ pair of homologous accounted for $44.16 \%$ and $51.67 \%$ in LWY and non-descript pigs, respectively.

A total of 116 and 82 numbers of NORs were noted on the $10^{\text {th }}$ chromosome in LWY crossbred and non-descript pig with mean number of 3.87 and 2.73 regions per animal, respectively (Table- 4 ). The share of silver deposits was calculated against their theoretically possible number, i.e., one individual can have four NORs, and so for 30 number of individuals of a given breed $100 \%$ accounted for $120(30 \times 4)$ Ag-NORs. The percentage share of deposits on the

Table-4: Frequency of occurrence of Ag-NORs in LWY crossbred and non-descript pigs ( $n=30$ animals).

\begin{tabular}{lccccccc}
\hline Breed & \multicolumn{3}{c}{ Chromosome pair 8 } & & \multicolumn{3}{c}{ Chromosome pair 10 } \\
\cline { 2 - 3 } & $\begin{array}{c}\text { Number of } \\
\text { Ag-NORs } \\
\text { observed }\end{array}$ & $\begin{array}{c}\text { Mean number } \\
\text { of NORs per } \\
\text { animal }\end{array}$ & $\begin{array}{c}\text { Share of } \\
\text { deposits (\%) }\end{array}$ & & $\begin{array}{c}\text { Number of } \\
\text { Ag-NORs } \\
\text { observed }\end{array}$ & $\begin{array}{c}\text { Mean number } \\
\text { of NORs per } \\
\text { animal }\end{array}$ & $\begin{array}{c}\text { Share of } \\
\text { deposits (\%) }\end{array}$ \\
\hline LWY & 52 & 1.76 & 44.16 & & 116 & 3.87 & 96.67 \\
$\begin{array}{l}\text { crossbred pig } \\
\text { Non-descript } \\
\text { pig }\end{array}$ & 61 & 2.16 & 51.67 & & 82 & 2.73 & 68.33
\end{tabular}

LWY=Large white Yorkshire, Ag-NORs=Silver-stained nucleolar organizer region 
$10^{\text {th }}$ pair of homologous accounted for $96.67 \%$ and $68.33 \%$ in LWY and non-descript pigs, respectively.

NORs of chromosome 10 are transcriptionally active in all cells and considered as the main site of rRNA production which was corroborated with the findings of previous studies $[1,9,17,20,22,23]$, whereas the NORs of chromosome 8 were not active to a variable degree. Liu et al. [24] stated that the polymorphism of Ag-NORs in pigs is caused mainly by differences in frequency of silver deposits on chromosome 8 .

\section{Conclusion}

The results confirmed differences across breeds in occurrence and number of NORs on chromosomes in pigs. The mean number of NORs present per metaphase varies between the animals indicating the existence of polymorphism for the number of NORs. A higher number of Ag-NORs were observed on chromosome pair 10 in both the genetic groups. It was concluded that NORs were more morphologically distinct and greater on chromosome pair 10 than on pair 8 , which suggests a dominant role of chromosome 10 in the global production of ribosomal RNA.

\section{Authors' Contributions}

VH and KSD planned and designed the whole study. VH collected samples, performed technique, and analyzed the data. KSD played a key role in data analysis. KSD, BPK, and JS helped during manuscript writing, crosschecking, and revision. All authors read and approved the final manuscript.

\section{Acknowledgments}

Authors owe sincere and earnest thanks to the Department of Animal Genetics and Breeding, Sri Venkateswara Veterinary University, Tirupati, for providing necessary research facilities to carry out the experiment and acknowledge the financial support through a research grant provided by "All India Coordinated Research Project on Pig", Tirupati. The authors are also thankful to the scientific and non-teaching staff of the farm for their kind attention during blood sample collection.

\section{Competing Interests} interests.

The authors declare that they have no competing

\section{References}

1. Bogdzińska, M., Araszkiewicz, J., Bartczak, K. and Mroczkowski, S. (2005) Polymorphism of nucleolar organizer regions on the $8^{\text {th }}$ pair of pig chromosomes. Folia Biol. (Praha), 53: 51-53.

2. Charon, K.M. and Switonski, M. (2000) Animal Genetics. PWN, Warszawa. p48-68.

3. Veerabhadrappa, S.K., Chandrappa, P.R., Roodmal, S.Y., Shetty, S.J., Shankari, G.S.M. and Kumar, K.P.M. (2016) Karyotyping: Current perspectives in diagnosis of chromosomal disorders. Sifa Med. J., 3(2): 35.

4. Arslan, A. and Albayrak, I. (2009) C-banded karyotype and nucleolar organizer regions (NORs) of wild boar, Sus scrofa (Artiodactyla: Suidae) from Anatolia. Turk. J. Biol., 33:29-33.
5. Słota, E. (1998) Polymorphism of Pig Chromosomes. Rocz Nauk Zoot. (Habilitation Thesis). p1-59.

6. Supanuam, P., Tanomtong, A., Khunsook, S., Sangpakdee, W., Pinthong, K., Sanoamuang, L.O. and Keawsri, S. (2012) Localization of nucleolar organizer regions (NORs) of four gibbon species in Thailand by Ag-NOR banding technique. Cytologia, 77(2): 141-148.

7. Naha, B.C., Prakesh, C. and Boro, P. (2016) Application of cytogenetic techniques in livestock improvement. Int. J. Sci. Nat., 7(1): 30-33.

8. Neeru, N., Bhatnagar, A. and Yadav, A. S. (2018) A study of constitutive heterochromatin and NOR banding in three species of Indian major carps from the State of Haryana, India. J. App. Nat. Sci., 10(2): 535-539.

9. Danielak-Czech, B., Babicz, M., Kozubska-Sobocinska, A. and Rejduch, B. (2013) Size polymorphism survey of nucleolar organizer regions (NORs) in Hampshire boars. Ann. Univ. Mariae Curie-Sktodowska. Sect. EE Zootech., 4(31): 8-13.

10. Trifonov, V.A., Paoletti, A., Barucchi, V.C., Kalinina, T., O'Brien, P.C., Ferguson-Smith, M.A. and Giovannotti, M. (2015) Comparative chromosome painting and NOR distribution suggest a complex hybrid origin of triploid Lepidodactylus lugubris (Gekkonidae). PLoS One, 10(7): e0132380.

11. Unal, S., Gaffaroğlu, M., Ayata, M.K. and Yüksel, E. (2014) Karyotype, C-banding and AgNORs of two endemic leuciscine fish, Pseudophoxinus crassus (Ladiges, 1960) and P. hittitorum Freyhof and Özulug, 2010 (Teleostei, Cyprinidae). Comp. Cytogenet., 8(4): 249.

12. Nabais, C., Rampin, M. and Collares-Pereira, M.J. (2013) Comparative cytogenetics of two endangered leuciscine fish, Squalius aradensis and Squalius torgalensis (Teleostei, Cyprinidae), from the Iberian Peninsula. Comp. Cytogenet., 7(1): 33 .

13. Moorehead, P.S., Nowell, P.C., Mellman, W.J., Batthips, D.M. and Hungerford, D.A. (1960) Chromosome preparation of leucocytes cultured from human peripheral blood. Exp. Cell Res., 20: 613-616.

14. Howell, W.M. and Black, D.A. (1978) A rapid technique for producing silver-stained nucleolus organizer regions and trypsin-giemsa bands on human chromosomes. Int. J. Hum. Genet., 43(1): 53-56.

15. Scedecor, G.W. and Cochran, G.W. (1989) Statistical Methods. $8^{\text {th }}$ ed. Iowa State University Press, Ames, Iowa.

16. Liu, W.S., Liu, X.D. and Zhan, T.S. (1989) Studies on polymorphism of Ag-NORs of several pig breeds in the area of Northwestern China. Acta Vet. Zootech. Sinica, 20: 209-214.

17. Mellink, C.H.M., Bosma, A.A., De Haan, N.A. and Wiegant, J. (1991) Distribution of rRNA genes in breeds of domestic pig studied by non-radioactive in situ hybridization and selective silver-staining. Genet. Sel. Evol., 23(1): 1.

18. Sohn, S.H., Kweon, O.S., Baik, K.H., Jung, W., Cho, E.J. and Kang, M.Y. (2003) G-, C- and NOR-banding of Korean native pig chromosomes. J. Anim. Sci. Technol., 45(6): 901-910.

19. Devi, P.U., Gupta, B.R., Devi, K.S. and Lakshmi, K.D. (2013) Nucleolus organizer region (NOR) banding in Mahabubnagar local goats. Tamilnadu J. Vet. Anim. Sci., 9(3): 227-230.

20. Mellink, C.H.M., Bosma, A.A. and Haan, N.A. (1994) Variation in size of Ag-NORs and fluorescent rDNA in situ hybridization signals in six breeds of domestic pig. Hereditas, 120(2): 141-149.

21. Popescu, C.P., Boscher, J. and Malynicz, G.L. (1988) Chromosome R-banding patterns and NOR homologies in the European wild pig and four breeds of domestic pig. Ann. Genet., 32(3): 136-140.

22. Nombela, J.A., Murcia, C.R., Abaigar, T. and Vericad, J.R. (1990) Cytogenetic analysis (GTG, CBG and NOR bands) of a wild boar population (Sus scrofa scrofa) with 
chromosomal polymorphism in the South-East of Spain. Genet. Sel. Evol., 22(1): 1-9.

23. Danielak-Czech, B., Rejduch, B. and Babicz, M. (2011) Cytomolecular assay of size nucleolar organizer regions (NORs) polymorphism in Pietrain pigs. Ann. Univ. Mariae
Curie Skłodowska. Sect. EE Zootech., 4(29): 33-38.

24. Liu, W.S., Lu, X.Z. and Qiu, H. (1995) Number and distribution of silver-stained nucleolar organizer regions and evolutionary relationships in domestic pigs. Anim. Genet., 26(5): 293-298.

$* * * * * * * *$ 